\title{
Anesthetic efficacy of $4 \%$ articaine buccal infiltration in the urgency treatment of mandibular molars with symptomatic irreversible pulpitis: a randomized clinical
}

\section{trial}

\author{
Eficácia anestésica da solução de articaína $4 \%$ pela técnica infiltrativa vestibular no tratamento de \\ urgência de molares inferiores com pulpite irreversível sintomática: ensaio clínico randomizado
} Eficacia de la articaína al $4 \%$ por la técnica de infiltración vestibular en el tratamiento de urgencia de molares mandibulares con pulpitis irreversible sintomática: ensayo clínico randomizado

\begin{abstract}
The aim of this study was to evaluate the anesthetic efficacy of the $4 \%$ articaine by the buccal infiltration technique (BI) after inferior alveolar nerve block (IANB) with $2 \%$ mepivacaine, both with 1:100,000 epinephrine, in the urgency treatment of mandibular molars with symptomatic irreversible pulpitis (SIP). This was a prospective study, with a randomized, blinded, controlled parallel clinical trial experimental design. Thirty patients diagnosed with SIP were randomly assigned, and the control group (G1) received the IANB with $1.8 \mathrm{~mL}$ of mepivacaine while the experimental group (G2) also received a supplemental BI with $1.8 \mathrm{~mL}$ of articaine. To evaluate the anesthetic efficacy, in addition to lip numbness test, the electric pulp testing (EPT) was used. Additionally, a visual analogue scale verified the presence of pain. Two-way ANOVA and Chi-square tests were applied at a significance level of $5 \%$. There was a reduction in pain perception after the two techniques $(p<0.001)$, with no difference between groups $(p=0.479)$. The anesthetic efficacy was $26.6 \%$ for IANB (G1) and $40 \%$ for IANB plus BI (G2), without significant difference between the two treatments $(p=0.699)$. The BI with $4 \%$ articaine after IANB with $2 \%$ mepivacaine, both with 1:100,000 epinephrine, did not significantly increase anesthetic success in patients with SIP.
\end{abstract}

Keywords: Articaine; Dental anesthesia; Dental pulp test; Endodontics; Pulpitis.

\section{Resumo}

O objetivo deste estudo foi avaliar a eficácia anestésica da articaína 4\% pela técnica infiltrativa vestibular (IV) após bloqueio do nervo alveolar inferior (BNAI) com mepivacaína $2 \%$, ambos com epinefrina 1:100.000, no tratamento de urgência de molares inferiores com pulpite irreversível sintomática (PIS). Trata-se de um estudo prospectivo, com delineamento experimental do tipo ensaio clínico randomizado paralelo controlado cego. Trinta pacientes com diagnóstico de PIS foram alocados aleatoriamente, sendo que o grupo controle (G1) recebeu o BNAI com 1,8 mL de 
mepivacaína, enquanto o grupo experimental (G2) recebeu também uma IV suplementar com 1,8 mL de articaína. Para avaliar a eficácia anestésica, além da análise da dormência labial, utilizou-se o teste de sensibilidade elétrico (TSE). Além disso, uma escala analógica visual verificou a presença de dor. Os testes ANOVA de dois fatores e Qui-quadrado foram aplicados a um nível de significância igual a 5\%. Houve redução da percepção da dor após as duas técnicas (p $<0,001)$, sem diferença entre os grupos $(p=0,479)$. A eficácia anestésica foi de $26,6 \%$ para o BNAI (G1) e 40\% para o $\mathrm{BNAI}+\mathrm{IV}(\mathrm{G} 2)$, sem diferença significativa entre os dois tratamentos $(\mathrm{p}=0,699)$. A IV com articaína 4\% após o BNAI com mepivacaína 2\%, ambos com epinefrina 1:100.000, não aumentou significativamente o sucesso anestésico em pacientes com PIS.

Palavras-chave: Anestesia dentária; Articaína; Endodontia; Pulpite; Teste da polpa dentária.

\section{Resumen}

El objetivo de este estudio fue evaluar la eficacia anestésica de la articaína al 4\% por la técnica de infiltración vestibular (IV) tras el bloqueo del nervio alveolar inferior (BNAI) con mepivacaína al 2\%, ambas con epinefrina 1: 100.000, en el tratamiento de urgencia de molares mandibulares con pulpitis irreversible sintomática (PIS). Se trata de un estudio prospectivo, con un diseño experimental del tipo de ensayo clínico randomizado paralelo controlado y ciego. Treinta pacientes diagnosticados con PIS fueron asignados aleatoriamente, con el grupo control (G1) recibiendo el BNAI con $1.8 \mathrm{~mL}$ de mepivacaína, mientras que el grupo experimental (G2) también recibió la IV con $1.8 \mathrm{~mL}$ de articaína. Para evaluar la eficacia anestésica, se utilizó el análisis labial y la prueba de sensibilidad eléctrica (PSE). Además, una escala visual analógica verificó la presencia de dolor. Se aplicaron ANOVA de dos vías y la prueba de chi-cuadrado a un nivel de significancia del 5\%. Hubo una reducción en la percepción del dolor después de ambas técnicas (p <0,001), sin diferencias entre los grupos $(\mathrm{p}=0,479)$. Las tasas de éxito anestésico fueron $26,6 \%$ para BNAI $(\mathrm{G} 1)$ y $40 \%$ para BNAI + IV (G2), sin diferencias significativas entre los dos tratamientos ( $p=0,699)$. La IV con articaína al 4\% después de BNAI con mepivacaína al 2\%, ambos con epinefrina 1: 100.000, no aumentó significativamente el éxito anestésico en pacientes con PIS.

Palabras clave: Anestesia dental; Articaína; Endodoncia; Pulpitis; Prueba de la pulpa dental.

\section{Introduction}

The inferior alveolar nerve block (IANB) is the most commonly used mandibular block injection technique to obtain local anesthesia for mandibular molar endodontic treatment (Claffey, Reader, Nusstein, Beck, \& Weaver, 2004; Fowler \& Reader, 2013; Oleson, Drum, Reader, Nusstein, \& Beck, 2010). However, IANB does not always result in successful pulpal anesthesia (Claffey et al., 2004; Fowler \& Reader, 2013; Oleson et al., 2010; Rogers, Botero, McDonald, Gardner, \& Peters, 2014). Teeth with symptomatic irreversible pulpitis (SIP) show greater difficulty in achieving anesthesia during endodontic treatment (Abazarpoor, Parirokh, Nakhaee, \& Abbott, 2015; Modaresi, Dianat, \& Soluti, 2008; Shapiro, McDonald, Gardner, Peters, \& Botero, 2018). Recent clinical studies in patients with SIP in mandibular molars have shown failure rates of IANB from $67 \%$ to $77 \%$ (Aggarwal, Jain, \& Kabi, 2009; Aggarwal, Singla, \& Miglani, 2017). These reduced success rates can be attributed to changes induced by inflammation in nociceptors (Aggarwal et al., 2017; Hargreaves \& Keiser, 2002). In addition, other hypotheses have been raised, such as anatomical reasons, effect of inflammation on local tissue pH, psychological factors (Hargreaves \& Keiser, 2002; Meechan, 2005), acute tachyphylaxis and inflammation effect on blood flow and central sensitization (Hargreaves \& Keiser, 2002).

It is a challenge for the clinician to manage endodontic urgencies related to pain in mandibular molar with irreversible pulpitis (Aggarwal et al., 2018). Professionals need to consider complementary techniques when the IANB fails to provide pulpal anesthesia for patients with SIP (Matthews, Drum, Reader, Nusstein, \& Beck, 2009). In order to increase anesthetic success rates, various supplementary injection techniques have been used (Aggarwal, Singla, Miglani, \& Kohli, 2019), including intraosseous, intrapulpal (Rogers et al., 2014; Shapiro et al., 2018), intraligamentary injections and buccal infiltrations (BI) (Webster et al., 2016).

One of the most commonly used anesthetics in clinical trials evaluating BI in cases of SIP is articaine. The possible mechanisms of action associated with a BI with articaine are: I) cancels the accessory supply of other nerves, such as the buccal nerve; II) provides localized anesthesia similar to a maxillary infiltration; III) reaches the inferior alveolar nerve canal, blocking the inferior alveolar nerve distal at that point; and IV) reaches the mental foramen (Meechan, 2011). 
When the BI with articaine was applied alone in patients with mandibular molars with SIP, it provided a significantly higher anesthetic success rate (40\%) when compared to IANB with lidocaine (10\%) (Monteiro, Groppo, Haiter-Neto, Volpato, $\&$ Almeida, 2015). In addition, when the IANB with lidocaine failed in $72 \%$ of the mandibular first molars and $75 \%$ of the mandibular second molars with SIP, a BI with articaine in these teeth reduced these rates to 58\% and 52\%, respectively (Fowler, Drum, Reader, \& Beck, 2016).

A common method for assessing the clinical success of IANB is to ask patients whether the lip is numb (Fowler, Reader, \& Beck, 2015). However, soft tissue anesthesia after administration of IANB only indicates that the injection was administered at the correct site, but does not guarantee pulpal anesthesia (Abazarpoor et al., 2015; Akhlaghi, Hormozi, Abbott, \& Khalilak, 2016). Currently, there is no standard method for assessing the anesthetic level, but cold and electric pulp testing (EPT) are used to evaluate anesthetic success (Hsiao-Wu, Susarla, \& White, 2007).

Lidocaine is still the anesthetic used as the standard for comparison in clinical trials evaluating anesthetic efficacy of IANB in different clinical situations (Poorni, Veniashok, Senthilkumar, Indira, \& Ramachandran, 2011). In view of this reality, there is a need for further investigation on the use of IANB with mepivacaine and its complementation through BI with articaine in patients with SIP. Therefore, the goal of the present study was to clinically evaluate the anesthetic efficacy of the $4 \%$ articaine solution by BI after IANB with 2\% mepivacaine, both with 1: 100,000 epinephrine, in the urgency treatment of mandibular molars diagnosed with SIP. The null hypothesis tested was that the BI with articaine would not increase the anesthetic success in patients with SIP.

\section{Methodology}

This was a prospective study, with a randomized, blinded, controlled parallel clinical trial experimental design, approved by the Standing Committee on Ethics in Human Research (COPEP) of the State University of Maringá (UEM) under the certificate 2.326.949, and registered at Brazilian Clinical Trials Registry (ReBec) (RBR-248jys). The study was conducted in accordance with the Declaration of Helsinki. All patients who passed the selection criteria agreed to participate voluntarily in the research and signed the Informed Consent Term.

A sample was selected following the guidelines of the CONSORT group (Figure 1). Patients could be included according to the following characteristics: painful symptomatology in one or more mandibular molars, SIP, ASA I and ASA II patients, teeth that could be isolated and rehabilitated. Exclusion criteria were: patients under 18 years of age, pregnant and lactating women, allergic to local anesthetics, using drugs that alter the pain threshold, immature teeth, root fracture and absence of lip numbness. All patients were attended to the Urgency Department with SIP in mandibular molars. 
Figure 1. CONSORT flow diagram.

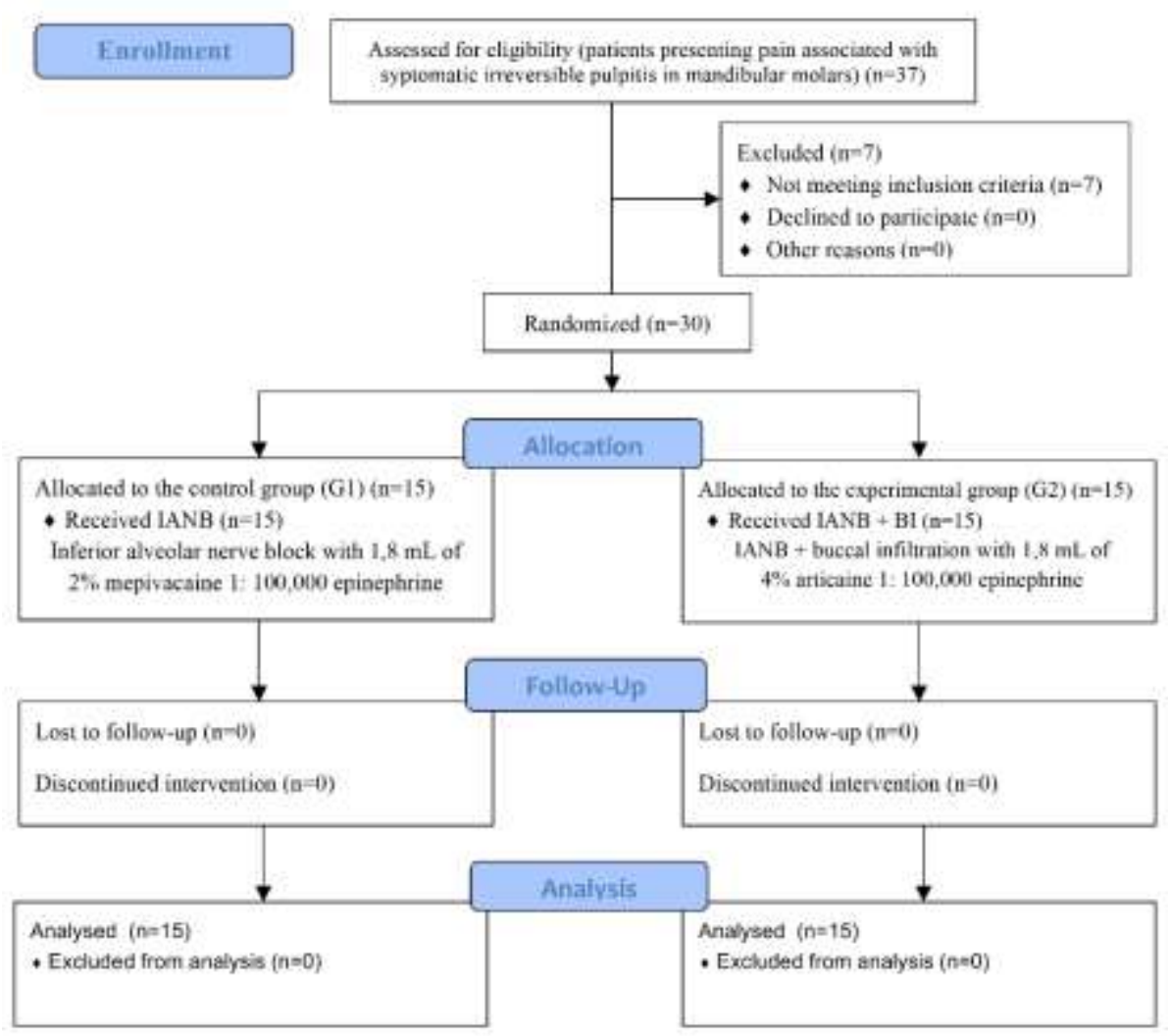

Source: Authors.

The distribution of the included participants occurred according to the anesthetic technique to be used, at random. Therefore, there was randomization by blocks of six people, allowing both interventions from the beginning of the study. The randomization occurred blinded by the emergency department employee, choosing a card and designating the treatment that this participant received. The volunteers were randomly assigned to two groups (Table 1), being one control group (G1) and one experimental group (G2).

Table 1. Distribution of patients according to the technique used.

\begin{tabular}{cccc}
\hline Group & Technique & Anesthetics & $\mathbf{n}$ \\
\hline G1 & IANB & $2 \%$ mepivacaine & 15 \\
G2 & IANB + BI & $2 \%$ mepivacaine $+4 \%$ articaine & 15
\end{tabular}

* G1: control group; G2: experimental group; IANB: inferior alveolar nerve block; BI: buccal infiltration. Source: Authors.

Initially, a modified 170-mm Heft-Parker visual analogue scale (HP VAS) was used to verify the perception of pain before initiation of treatment. It was composed of six categorical scales (faint, weak, mild, moderate, severe, and intense) on a VAS line with the ends labeled "no pain" and "unbearable pain" (Aggarwal et al., 2019). The HP VAS was used again 5 minutes after the anesthetic techniques and during the treatment if there was any pain.

According to American Association of Endodontists [AAE] (2009), the diagnosis of SIP was obtained with the cold pulp testing and performed by the same clinician who did the anesthetic techniques. Before the test, the patients were reassured, informed about the test, and asked to raise their hands when they felt pain and lower when pain subsided. After the isolation 
with cotton and drying with air, the refrigerant spray (Endo-Ice; Maquira, Maringá, PR, Brazil) was first applied on a cotton wool ball for two seconds and immediately taken to the buccal surface of the tooth, until the moment the patient presented sensibility. Pulpal sensibility tests were first evaluated on a corresponding contralateral tooth.

In both groups, topical anesthesia (Benzotop; Nova DFL, Rio de Janeiro, RJ, Brazil) was directly applied in the region of needle insertion for two minutes. Subsequently, the patients received the IANB with $1.8 \mathrm{~mL}$ of $2 \%$ mepivacaine with 1 : 100,000 epinephrine (Mepiadre; Nova DFL, Rio de Janeiro, RJ, Brazil) with a 27-G long needle (Unoject; Nova DFL, Rio de Janeiro, RJ, Brazil) and a direct approach (Halsted) with a duration of two minutes. IANB should necessarily be accompanied by profound lip numbness on the anesthetized side. If lip numbness was not recorded within ten minutes, the patients were excluded from the study.

For the participants assigned to G2, the BI with $1.8 \mathrm{~mL}$ of $4 \%$ articaine with 1: 100,000 epinephrine (Articaine; Nova DFL, Rio de Janeiro, RJ, Brazil) was used as complementation shortly after IANB. For this, a short needle 30G (Nova DFL) was inserted gently into the alveolar mucosa and penetrated to the point where it was estimated to be at or slightly above the apexes of the tooth to be treated (Matthews et al., 2009). Articaine was injected between the roots with a total time of two minutes. The techniques were performed by an endodontic specialist with experience in cases of urgency.

The EPT, performed by an operator who was not aware of the anesthetic technique used, contributed to the diagnosis of pulpal anesthesia. After 5 minutes of the injections according to the group (G1 or G2), the isolation, drying and placement of toothpaste on the vestibular surface were given to improve electrical conduction. The device (Denjoy DY310 Dental Pulp Tester; Denjoy, Changsha, Hunan, China) had a tip positioned to pass the current. In cases of negative response to a maximal reading $(80 \mu \mathrm{A})$, the treatment was initiated. In positive responses, another 5 minutes were waited and the EPT was repeated. In cases in which the response was positive within 5 or 10 minutes, or those which the patient felt any pain during the treatment (HP VAS $>0 \mathrm{~mm}$ ), were recorded as failure of the technique. The supplemental techniques used in cases of failure were BI, intraligamentary or intrapulpal injections. The treatment was finished with the pulpectomy, insertion of the calcium hydroxide (Biodinâmica, Ibiporã, PR, Brazil) paste associated with propylene glycol and sealing with a temporary filling material (IRM; Dentsply Sirona, York, Pennsylvania, USA). All participants were referred to proceed with root canal filling and final restoration.

The results were recorded in a Microsoft Excel worksheet (Microsoft Office Excel 2017; Microsoft Corp, Redmond, Washington, USA) and subjected to descriptive analysis. Subsequently, two-way ANOVA with repeated measures was applied to verify pain reduction since the same patient was observed at two different times. The association of treatments with the dependent variable, categorized as dichotomous (success or failure), was verified by Chi-square test. The analyses were done by using R version 3.5, with a level of significance set at $5 \%$.

\section{Results}

Nineteen female patients and 11 male patients were included in the study, with a mean age of $37.8( \pm 13)$ years and the first mandibular molar most frequently affected with SIP (56.7\%). None of the 30 patients included had any adverse effect resulting from the application of the techniques and anesthetics used. All participants (100\%) reported profound lip numbness on the side where anesthetic techniques were applied.

In G1, the mean pain sensation measured by HP VAS before initiation of treatment was $128.9 \mathrm{~mm}$ (strong - intense), and reduced to $15.9 \mathrm{~mm}$ (none - weak) after the IANB. In G2, it was $132.4 \mathrm{~mm}$ (strong - intense), and reduced to $3.5 \mathrm{~mm}$ (none - weak) after the IANB combined with BI (Figure 2). Two-way ANOVA indicated a significant reduction of pain after anesthetic techniques for both $\mathrm{G} 1$ and $\mathrm{G} 2$ ( $\mathrm{p}<0.001$ ), with no difference between them ( $\mathrm{p}=0.479)$. 
Figure 2. A. Box plot of pain intensity before and after the application of the anesthetic techniques.B. Profile plot of pain intensity before and after the application of the anesthetic techniques.

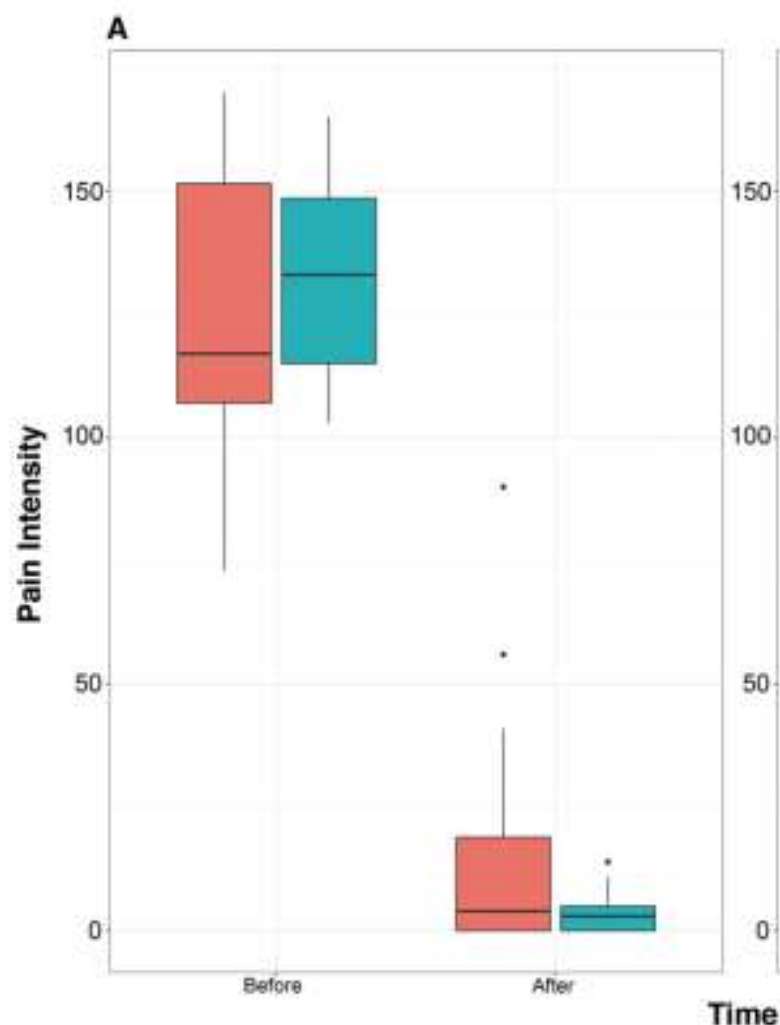

B

Time

* IANB: inferior alveolar nerve block; BI: buccal infiltration. Source: Authors.

The primary anesthesia measured by EPT can be verified in table 2. The presence of false negatives modified the final anesthetic success rates for both groups (Table 3). False-negative results were obtained in five G1 patients (55.5\%) and four G2 patients (40\%). The permanence of pain in these cases was detected with HP VAS and the mean was 81.4 mm (mild - moderate) and $64 \mathrm{~mm}$ (mild - moderate) for G1 and G2, respectively. Chi-square test indicated that there was no association between the group and anesthetic success, that is, there was no significant difference between the G1 and G2 (p=0.699).

Table 2. Comparison of primary anesthesia measured by the electric pulp testing between groups.

\begin{tabular}{cccc}
\hline \multicolumn{1}{c}{ EPT } & & G1 & G2 \\
\hline & Negative & $9(60 \%)$ & $10(66,7 \%)$ \\
& Positive & $6(40 \%)$ & $5(33,3 \%)$
\end{tabular}

* G1: control group; G2: experimental group; EPT: electric pulp testing. Source: Authors.

Table 3. Comparison of final anesthetic success and failure between control group and experimental group.

\begin{tabular}{ccc}
\hline & G1 & G2 \\
\hline Final success & $4(26.7 \%)$ & $6(40 \%)$ \\
Failure & $11(73.3 \%)$ & $9(60 \%)$ \\
\hline
\end{tabular}

* G1: control group; G2: experimental group. Source: Authors. 


\section{Discussion}

Clinically, there is a difficulty in obtaining satisfactory anesthesia in teeth with SIP (Abazarpoor et al., 2015; Aggarwal et al., 2019; Modaresi et al., 2008; Poorni et al., 2011; Shapiro et al., 2018), and this contributes to the increase of anxiety in patients (Shahi, Rahimi, Yavari, Ghasemi, \& Ahmadi, 2018) and undermines the predictability of the treatment. With the results obtained, it was possible to detect that none of the G1 (IANB) or G2 (IANB + BI) techniques promoted 100\% anesthetic success, as previously found by Akhlaghi et al. (2016) and Ashraf, Kazem, Dianat and Noghrehkar (2013). In the present study, there was $73.3 \%$ failure in G1, in which only IANB was applied, and $60 \%$ of G2 individuals were characterized with failure. The results found for failure rates when investigating available literature are heterogeneous and may reach 83\% for IANB (Aggarwal et al., 2017) and $85 \%$ for IANB combined with BI (Akhlaghi et al., 2016), depending on the anesthetic solution and methodologies applied.

Corroborating the present study, VAS such as the Heft-Parker scale (Heft \& Parker, 1984) or modified HP VAS, were used as a means of assessing pain by other authors (Abazarpoor et al., 2015; Aggarwal et al., 2012, 2017, 2018, 2019; Akhlaghi et al., 2016; Ashraf et al., 2013; Claffey et al., 2004; Fowler et al., 2016; Khademi, Saatchi, Minaiyan, Rostamizadeh, \& Sharafi, 2012; Matthews et al., 2009; Monteiro et al., 2015; Pedro-Muñoz \& Mena-Álvarez, 2017; Rodríguez-Wong, Pozos-Guillen, Silva-Herzog, \& Chavarría-Bolaños, 2016). HP VAS is primarily used to include subjects in the studies and assess pain during treatment. However, while some studies define as a factor of anesthetic success the intensity of the pain to be less than $55 \mathrm{~mm}$ in HP VAS during the pulpectomy (Abazarpoor et al., 2015; Aggarwal et al., 2009, 2012, 2017, 2018, 2019; Akhlaghi et al., 2016; Ashraf et al., 2013; Claffey et al., 2004; Fowler et al., 2013, 2016; Khademi et al., 2012; Matthews et al., 2009), others adopt the absence of pain $(0 \mathrm{~mm})$ as a parameter (Kanaa, Whitworth, \& Meechan, 2012; Pedro-Muñoz \& Mena-Álvarez, 2017; Rodríguez-Wong et al., 2016). Considering the possibility of maximum comfort during the treatment, we used as a parameter the absence of pain as a criterion for anesthetic success. HP VAS was also used to investigate the reduction of symptoms soon after anesthetic techniques. It is evident in figure 2 that there was a significant decrease in pain perception in all patients after initial anesthetic techniques ( $p<0.001$ ), a benefit also observed in previous clinical trials (Aggarwal et al., 2009, 2012). In G2, there was also a lower sensation of pain in the false-negative cases (64 mm, mild to moderate). These findings associated with clinical evidence suggests that patients complemented with BI feel greater anesthetic comfort during therapy and tend to undergo a more predictable treatment, thus showing that this technique may be an alternative in SIP cases.

The present study's final anesthetic success was $26.7 \%$ in patients who received IANB with 1.8 mL of $2 \%$ mepivacaine with 1: 100,000 epinephrine (G1). Rodríguez-Wong et al. (2016) and Noguera-Gonzalez, Cerda-Cristerna, Chavarria-Bolaños, Flores-Reyes and Pozos-Guillen (2013) used control groups with the same volume and concentration of mepivacaine in IANB in patients with SIP and obtained final success rates of $36 \%$ and $46.4 \%$, respectively. However, unlike this study, the initial method for assessing anesthesia was the cold sensitivity test. Besides, the patients of the research conducted by NogueraGonzalez et al. (2013) received a placebo pill one hour before anesthesia, and there may be a psychological factor involved, restricting the comparison with our results. When Visconti, Tortamano and Buscariolo (2016) increased the anesthetic volume to $3.6 \mathrm{~mL}$ of mepivacaine after the failure of the first injection in IANB, they found no statistical differences in anesthetic success.

The anesthetic success obtained with the BI supplemental technique with $1.8 \mathrm{~mL}$ of $4 \%$ articaine with 1: 100,000 epinephrine was 40\%. Chi-square test indicated no statistically significant difference when comparing G1 and G2 for final anesthetic success $(\mathrm{p}=0.699)$. To date, we have not found any investigations that evaluated the anesthetic success by associating articaine and mepivacaine in patients with SIP, so a discussion in this sense is limited. When Matthews et al. (2009) used 1.8 $\mathrm{mL}$ of lidocaine in IANB and $1.8 \mathrm{~mL}$ of articaine in BI, they obtained anesthetic success in $58 \%$ of the first molars and $48 \%$ of the second molars. Fowler et al. (2016) increased the volume to $3.6 \mathrm{~mL}$ of lidocaine in the IANB before BI with articaine in part of the patients and found success rates of $42 \%$ for lower first molars and $48 \%$ for lower second molars. Unfortunately, success 
and failure percentages were not individually described for the different volumes applied in the study by Fowler et al. (2016). Besides that, the highest success rates found by these authors may be related to the fact that anesthetic success was also considered when the HP VAS response did not exceed $55 \mathrm{~mm}$. The highest success rate with the IANB plus BI was found by Kanaa et al. (2012) when they performed the pulpectomy in $85 \%$ of the mandibular molars without the need for anesthetic complementation. In addition to the higher concentration of vasoconstrictor in IANB (1: 80,000 epinephrine), these authors used $2.0 \mathrm{~mL}$ solution for both the IANB with lidocaine and the BI with articaine. Different from our study, in which the EPT operator was not aware of the anesthetic technique performed, the tests for anesthesia in the study of Kanaa et al. (2012) were performed by the same clinician of the different complementary injections applied. On the other hand, the lowest success rate with the IANB plus BI technique was only $15 \%$ when using $1.8 \mathrm{~mL}$ and $0.9 \mathrm{~mL}$ of articaine in IANB and BI, respectively (Akhlaghi et al., 2016).

Local anesthesia in the mandible traditionally has been provided by employing IANB (Meechan, 2005), and it is crucial to determine if it was achieved before beginning the treatment (Nusstein, Reader, \& Drum, 2010). It is known that soft tissue anesthesia, such as lip, after administration of IANB does not guarantee pulpal anesthesia (Abazarpoor et al., 2015; Akhlaghi et al., 2016). However, some studies still consider only lip numbness as a criterion for evaluating initial anesthesia, without the use of sensitivity tests (Khademi et al., 2012; Matthews et al., 2009). Rodríguez-Wong et al. (2016) observed that when there is a negative response to the cold sensitivity test to check pulpal anesthesia in teeth with SIP, patients may experience pain during coronary access. This setback also exists when using the EPT. At a maximum electric stimulation $(80 \mu \mathrm{A})$, the EPT can accurately determine pulpal anesthesia in teeth with normal pulp (Nusstein et al., 2010), but in teeth with SIP, the results may not be reflected clinically (Dreven, Reader, Beck, Meyers, \& Weaver, 1987). Even with a failure to respond to the stimulus, the patient may still report pain during the treatment (false-negative results) (Nusstein et al., 2010), a fact also found in the participants of this clinical research. False-negative responses were obtained in 55.5\% (G1) and 40\% (G2) of the participants.

It is highlighted as a differential of the present study, the use of BI with articaine after the IANB with mepivacaine. Mepivacaine has a lower ionization constant ( $\mathrm{pKa}$ ) than lidocaine, and is therefore more compatible with inflamed tissues and has a shorter onset of action (Visconti et al., 2016). Thus, new studies using mepivacaine combined with articaine in patients diagnosed with SIP are required. In addition, as there is evidence of increased anesthetic success in patients with SIP with the use of injectable tramadol (Pedro-Muñoz \& Mena-Álvarez, 2017), increased anesthetic volume (Abazarpoor et al., 2015; Aggarwal et al., 2012) and BI with ketorolac tromethamine (Akhlaghi et al., 2016), investigations with these alternative resources may also be considered.

\section{Conclusion}

In conclusion, the buccal infiltration technique with $4 \%$ articaine after the inferior alveolar nerve block with $2 \%$ mepivacaine, both with 1: 100,000 epinephrine, did not significantly increase the anesthetic success in patients with symptomatic irreversible pulpitis.

\section{References}

AAE consensus conference recommended diagnostic terminology. (2009). Journal of Endodontics, 35, 1634. 10.1016/j.joen.2009.09.035.

Abazarpoor, R., Parirokh, M., Nakhaee, N., \& Abbott, P. V. (2015). A comparison of different volumes of articaine for inferior alveolar nerve block for molar teeth with symptomatic irreversible pulpitis. Journal of Endodontics, 41(9), 1408-11. 10.1016/j.joen.2015.05.015.

Aggarwal, V., Jain, A., \& Kabi, D. (2009). Anesthetic efficacy of supplemental buccal and lingual infiltrations of articaine and lidocaine after an inferior alveolar nerve block in patients with irreversible pulpitis. Journal of Endodontics, 35(7), 925-9. 10.1016/j.joen.2009.04.012.

Aggarwal, V., Singla, M., \& Miglani, S. (2017). Comparative evaluation of anesthetic efficacy of $2 \%$ lidocaine, $4 \%$ articaine, and $0.5 \%$ bupivacaine on inferior alveolar nerve block in patients with symptomatic irreversible pulpitis: a prospective, randomized, double-blind clinical trial. Journal of Oral \& Facial Pain and 
Headache, 31(2), 124-8. 10.11607/ofph.1642.

Aggarwal, V., Singla, M., Miglani, S., \& Kohli, S. (2019). Efficacy of articaine versus lidocaine administered as supplementary intraligamentary injection after a failed inferior alveolar nerve block: a randomized double-blind study. Journal of Endodontics, 45(1), 1-5. 10.1016/j.joen.2018.09.012.

Aggarwal, V., Singla, M., Miglani, S., Kohli, S., Sharma, V., \& Bhasin, S. S. (2018). Does the volume of supplemental intraligamentary injections affect the anaesthetic success rate after a failed primary inferior alveolar nerve block? A randomized-double blind clinical trial. International Endodontic Journal, 51(1), 5-11. 10.1111/iej.12773.

Aggarwal, V., Singla, M., Miglani, S., Kohli, S., \& Singh, S. (2012). Comparative evaluation of $1.8 \mathrm{~mL}$ and $3.6 \mathrm{~mL}$ of $2 \%$ lidocaine with 1:200,000 epinephrine for inferior alveolar nerve block in patients with irreversible pulpitis: a prospective, randomized single-blind study. Journal of Endodontics, 38(6), 753-6. 10.1016/j.joen.2012.02.003.

Akhlaghi, N. M., Hormozi, B., Abbott, P. V., \& Khalilak, Z. (2016). Efficacy of ketorolac buccal infiltrations and inferior alveolar nerve blocks in patients with irreversible pulpitis: a prospective, double-blind, randomized clinical trial. Journal of Endodontics, 42(5), 691-5. 10.1016/j.joen.2016.02.003.

Ashraf, H., Kazem, M., Dianat, O., \& Noghrehkar, F. (2013). Efficacy of articaine versus lidocaine in block and infiltration anesthesia administered in teeth with irreversible pulpitis: a prospective, randomized, double-blind study. Journal of Endodontics, 39(1), 6-10. 10.1016/j.joen.2012.10.012.

Claffey, E., Reader, A., Nusstein, J., Beck, M., \& Weaver J. (2004). Anesthetic efficacy of articaine for inferior alveolar nerve blocks in patients with irreversible pulpitis. Journal of Endodontics, 30(8), 568-71. 10.1097/01.don.0000125317.21892.8f.

Dreven, L. J., Reader, A., Beck, M., Meyers, W. J., \& Weaver, J. (1987). An evaluation of an electric pulp tester as a measure of analgesia in human vital teeth. Journal of Endodontics, 13(5), 233-8. 10.1016/s0099-2399(87)80097-3.

Fowler, S., Drum, M., Reader, A., \& Beck, M. (2016). Anesthetic success of an inferior alveolar nerve block and supplemental articaine buccal infiltration for molars and premolars in patients with symptomatic irreversible pulpitis. Journal of Endodontics, 42(3), 390-2. 10.1016/j.joen.2015.12.025.

Fowler, S., \& Reader, A. (2013). Is a volume of $3.6 \mathrm{~mL}$ better than $1.8 \mathrm{~mL}$ for inferior alveolar nerve blocks in patients with symptomatic irreversible pulpitis? Journal of Endodontics, 39(8), 970-2. 10.1016/j.joen.2013.04.007.

Fowler, S., Reader, A., \& Beck, M. (2015). Incidence of missed inferior alveolar nerve blocks in vital asymptomatic subjects and in patients with symptomatic irreversible pulpitis. Journal of Endodontics, 41(5), 637-9. 10.1016/j.joen.2015.01.029.

Hargreaves, K. M., \& Keiser, K. (2002). Local anesthetic failure in endodontics: mechanisms and management. Endodontic Topics, 1, 26-39. 10.1034/j.16011546.2002.10103.x

Heft, M. W., \& Parker, S. R. (1984). An experimental basis for revising the graphic rating scale for pain. Pain, 19(2), 153-61. 10.1016/0304-3959(84)90835-2.

Hsiao-Wu, G. W., Susarla, S. M., \& White, R. R. (2007). Use of the cold test as a measure of pulpal anesthesia during endodontic therapy: a randomized, blinded, placebo-controlled clinical trial. Journal of Endodontics, 33(4), 406-10. 10.1016/j.joen.2006.12.009.

Kanaa, M. D., Whitworth, J. M., \& Meechan, J. G. (2012). A prospective randomized trial of different supplementary local anesthetic techniques after failure of inferior alveolar nerve block in patients with irreversible pulpitis in mandibular teeth. Journal of Endodontics, 38(4), 421-5. 10.1016/j.joen.2011.12.006.

Khademi, A. A., Saatchi, M., Minaiyan, M., Rostamizadeh, N., \& Sharafi, F. (2012). Effect of preoperative alprazolam on the success of inferior alveolar nerve block for teeth with irreversible pulpitis. Journal of Endodontics, 38(10), 1337-9. 10.1016/j.joen.2012.06.007.

Matthews, R., Drum, M., Reader, A., Nusstein, J., \& Beck, M. (2009). Articaine for supplemental buccal mandibular infiltration anesthesia in patients with irreversible pulpitis when the inferior alveolar nerve block fails. Journal of Endodontics, 35(3), 343-6. 10.1016/j.joen.2008.11.025.

Meechan, J. G. (2005). Why does local anaesthesia not work everytime? Dental Update, 32(2), 66-72. 10.12968/denu.2005.32.2.66.

Meechan, J. G. (2011). The use of the mandibular infiltration anesthetic technique in adults. Journal of American Dental Association, 142 Suppl 3, 19S-24S. 10.14219/jada.archive.2011.0343.

Modaresi, J., Dianat, O., \& Soluti, A. (2008). Effect of pulp inflammation on nerve impulse quality with or without anesthesia. Journal of Endodontics, 34(4), 438-41. 10.1016/j.joen.2008.01.014.

Monteiro, M. R., Groppo, F. C., Haiter-Neto, F., Volpato, M. C., \& Almeida, J. F. (2015). 4\% articaine buccal infiltration versus $2 \%$ lidocaine inferior alveolar nerve block for emergency root canal treatment in mandibular molars with irreversible pulpits: a randomized clinical study. International Endodontic Journal, 48(2), 145-52. 10.1111/iej.12293.

Noguera-Gonzalez, D., Cerda-Cristerna, B. I., Chavarria-Bolaños, D., Flores-Reyes, H., \& Pozos-Guillen, A. (2013). Efficacy of preoperative ibuprofen on the success of inferior alveolar nerve block in patients with symptomatic irreversible pulpitis: a randomized clinical trial. International Endodontic Journal, 46(11), 1056-62. 10.1111/iej.12099.

Nusstein, J. M., Reader, A., \& Drum, M. (2010). Local anesthesia strategies for the patient with a "hot" tooth. Dental Clinics of North America, 54(2), 237-47. 10.1016/j.cden.2009.12.003.

Oleson, M., Drum, M., Reader, A., Nusstein, J., \& Beck, M. (2010). Effect of preoperative ibuprofen on the success of the inferior alveolar nerve block in patients with irreversible pulpitis. Journal of Endodontics, 36(3), 379-82. 10.1016/j.joen.2009.12.030.

Pedro-Muñoz, A. de, \& Mena-Álvarez, J. (2017). The effect of preoperative submucosal administration of tramadol on the success rate of inferior alveolar nerve block on mandibular molars with symptomatic irreversible pulpitis: a randomized, double-blind placebo-controlled clinical trial. International Endodontic Journal, 50(12), 1134-42. 10.1111/iej.12755. 
Research, Society and Development, v. 10, n. 5, e32910514651, 2021 (CC BY 4.0) | ISSN 2525-3409 | DOI: http://dx.doi.org/10.33448/rsd-v10i5.14651

Poorni, S., Veniashok, B., Senthilkumar, A. D., Indira, R., \& Ramachandran, S. (2011). Anesthetic efficacy of four percent articaine for pulpal anesthesia by using inferior alveolar nerve block and buccal infiltration techniques in patients with irreversible pulpitis: a prospective randomized double-blind clinical trial. Journal of Endodontics, 37(12), 1603-7. 10.1016/j.joen.2011.09.009.

Rodríguez-Wong, L., Pozos-Guillen, A., Silva-Herzog, D., \& Chavarría-Bolaños, D. (2016). Efficacy of mepivacaine-tramadol combination on the success of inferior alveolar nerve blocks in patients with symptomatic irreversible pulpitis: a randomized clinical trial. International Endodontic Journal, 49(4), 325-33. 10.1111/iej.12463.

Rogers, B. S., Botero, T. M., McDonald, N. J., Gardner, R. J., \& Peters, M. C. (2014). Efficacy of articaine versus lidocaine as a supplemental buccal infiltration in mandibular molars with irreversible pulpitis: a prospective, randomized, double-blind study. Journal of Endodontics, 40(6), 753-8. 10.1016/j.joen.2013.12.022.

Shahi, S., Rahimi, S., Yavari, H. R., Ghasemi, N., \& Ahmadi, F. (2018). Success rate of 3 injection methods with articaine for mandibular first molars with symptomatic irreversible pulpitis: a CONSORT randomized double-blind clinical trial. Journal of Endodontics, 44(10), 1462-6. 10.1016/j.joen.2018.07.010.

Shapiro, M. R., McDonald, N. J., Gardner, R. J., Peters, M. C., \& Botero, T. M. (2018). Efficacy of articaine versus lidocaine in supplemental infiltration for mandibular first versus second molars with irreversible pulpitis: a prospective, randomized, double-blind clinical trial. Journal of Endodontics, 44(4), 523-8. 10.1016/j.joen.2017.10.003

Visconti, R. P., Tortamano, I. P., \& Buscariolo, I. A. (2016). Comparison of the anesthetic efficacy of mepivacaine and lidocaine in patients with irreversible pulpitis: a double-blind randomized clinical trial. Journal of Endodontics, 42(9), 1314-9. 10.1016/j.joen.2016.06.015.

Webster, S., Drum, M., Reader, A., Fowler, S., Nusstein, J., \& Beck, M. (2016). How effective is supplemental intraseptal anesthesia in patients with symptomatic irreversible pulpitis? Journal of Endodontics, 42(10), 1453-7. 10.1016/j.joen.2016.07.002. 